\title{
PERMAINAN INOVATIF LEGHEZO SEBAGAI MEDIA EDUKASI KESEHATAN UNTUK ANAK-ANAK
}

\author{
Widodo Hariyono, Elisda Septiyani \\ Fakultas Kesehatan Masyarakat, Universitas Ahmad Dahlan
}

${ }^{*}$ Correspondence: widodohariyono@gmail.com. Telp: +6281393276184

Dikirimkan 07 Juli 2019; Diterima 15 Juli 2019; Dipublikasikan Agustus 2019

\begin{abstract}
Golden ages phase is an important period of growth and development of the children. This period is a very good time to cultivate the values of the character of goodness which will hopefully be able to shape his personality. One of them is about living clean and healthy. Leghezo is health education games for children. Leghezo was present because of the limited health education media at the time of the widespread use of gadgets by children. Leghezo is a product development of the Research and Develepment study level 3. The stages of the research include data collection, planning, product development, validation, and product trials. The feasibility of the product is based on the results of the assessment of media experts, material experts, and Elementary School (SD) students as test subjects. Data collection techniques using observation and questionnaires. Data analysis with qualitative descriptive. The results of the study, the assessment of media experts score 4.36 (feasible category), expert assessment of the material score 4.90 (feasible category), the initial field trial results are $100 \%$ (feasible category). In conclusion, the innovative Leghezo game is worthy of being a health education media for children aged between 7-13 years.
\end{abstract}

Keywords: Education media, Living clean and healthy, Games, Leghezo

\section{PENDAHULUAN}

Proses tumbuh kembang anak-anak terutama setelah fase golden ages merupakan periode penting dalam kehidupan. Kualitas seorang anak dapat dinilai dari proses tersebut. Setelah masa keemasannya, anak-anak beralih menuju fase bermain, sebab pada masa ini anak-anak mengalami perkembangan dalam kemampuan berbahasa, kreativitas, kesadaran sosial, emosional, dan inteligensi. Perkembangan pada masa tersebut akan menjadi landasan bagi perkembangan kemampuan dan potensi diri anak-anak. Pada masa inilah, waktu yang sangat baik untuk menumbuhkan nilai-nilai karakter kebaikan yang nantinya diharapkan akan dapat membentuk kepribadiannya. Atas dasar hal tersebut, sangat penting dilaksanakan penanaman nilai-nilai karakter pada anak-anak usia dini dalam mengoptimalkan bakat dan potensi yang dimiliki oleh anak(1).

Anak masa usia Sekolah Dasar (SD) merupakan individu yang terus memroses perkembangannya dengan pesat(2). Karakteristik utama anak, mereka memiliki kemampuan komunikasi yang belum matang, kemampuan kognitif yang masih terbatas, dan adanya perbedaan yang cukup besar antara pengetahuan yang dimiliki anak dibandingkan pada orang dewasa(3) Diperlukan pengoptimalan pertumbuhan dan perkembangan anak melalui pelatihan kemampuan kognitif anak, agar anak mampu meningkatkan daya eksplorasi dalam mengamati lingkungan sekitar melalui panca indera, juga dapat melangsungkan hidupnya, dan menjadi manusia utuh di masa mendatang(4). Menurut Prasetia dan Komaini bahwa kegiatan bermain anak-anak pada umur 5 tahun keatas sedang berada pada masa golden ages yaitu masa dimana psikomotorik anak sangat peka dalam menerima suatu rangsang, dan bilamana masa golden ages tersebut terlewatkan maka terlewatkanlah sudah kesempatan terbaik bagi anak tersebut(5).

Sejalan dengan perkembangan kemampuan anak dalam berkomunikasi, berbahasa, berkreativitas, bersosialisasi, dan berpikir, anak-anak usia Sekolah Dasar (SD) mengalami proses tersebut. Mereka memiliki kemampuan komunikasi 
yang belum matang dan kemampuan kognitif yang terbatas. Di sisi lain, pesatnya kemajuan teknologi informasi mengakibatkan anak-anak mudah terpapar alat-alat elektronik yang mengubah gaya hidup dan berpikir. Mereka juga belum sepenuhnya menerapkan kehidupan yang sehat dalam kesehariannya.

Tiga faktor yang mendasari penelitian pengembangan permainan edukasi kesehatan ini, yaitu: (1) anak-anak dalam keseharian belum memahami aspek sebab-akibat dan Perilaku Hidup Bersih dan Sehat/PHBS, (2) anak-anak belum memahami aspek sebab-akibat, (3) permainan atau alat peraga terkait edukasi kesehatan anak-anak belum ada atau masih terbatas, (4) realitas saat ini anak-anak telah terperangkap gadget dalam keseharian mereka. Ketiga aspek tersebut berpengaruh pada anak-anak usia 7-13 tahun yang merupakan masa yang tepat untuk mendapatkan pendidikan kedisiplinan dalam perilaku sehari-hari untuk menerapkan PHBS, misalnya mencuci tangan memakai sabun dan menggosok gigi secara teratur dan dengan cara benar.

Pendidikan merupakan hal yang sangat urgen dan berpengaruh besar dalam membentuk karakter anak yang menjadi cerminan kepribadian utuh pada seseorang, seperti sikap mental dan perilaku. Pendidikan juga dapat membantu siswa dalam mengembangkan potensi diri, kecakapan, serta karakteristik pribadinya ke arah yang positif, baik untuk dirinya maupun lingkungannya(6).

Konsep Taksonomi Bloom menggambarkan 3 hal yang menjadi acuan dalam mendidik, yaitu kognitif, afektif, dan psikomotorik. Saat ini terjadi penurunan kualitas moral anak SD akibat keterpaparan gadget(7) Berdasarkan penelitian yang dilakukan Viandari dan Susilawati bahwa penggunaan gadget berperan terhadap interaksi sosial anak prasekolah, sehingga semakin tingginya penggunaan media baru, interaksi sosial anak akan cenderung semakin rendah(8).

Maka, diperlukan pengoptimalan proses tumbuh kembang anak dalam fase bermain melalui media, dengan "langkah praktis" dalam memfasilitasi pendidikan kesehatan anak bagi kemampuan kognitif, afektif, dan psikomotorik. Untuk memahami dan menjalankan aspek kesehatan sehari-hari, diciptakan permainan baru bagi anak-anak yang bersifat edukatif, implementatif, dan terpantau, yang diberi nama "Leghezo", singkatan dari Let's Go to The Health Zone.

Terdapat peluang besar untuk melakukan perubahan dengan berkreasi dan berinovasi melalui media pendidikan anak. Leghezo menjadi peluang besar sebagai permainan anak untuk belajar PHBS sehari-hari dan menjadi potensi sebagai alat peraga permainan edukasi yang sangat menjanjikan. Pengembangan alat peraga permainan edukasi kesehatan Leghezo ini mengacu pada karakteristik siswa SD yang suka bermain. Bermain adalah suatu kegiatan yang dilakukan dengan atau tanpa memergunakan alat yang menghasilkan pengertian atau memberikan informasi, memberi kesenangan maupun mengembangkan imajinasi pada anak(9). Tujuan penelitian adalah menghasilkan dan mengembangkan Leghezo sebagai bentuk permainan inovatif, edukatif, implementatif, dan terpantau, bagi anak-anak usia antara 7-13 tahun.

\section{METODE PENELITIAN}

Jenis penelitian yang digunakan adalah model simulasi uji pengembangan produk atau Research and Development $(R \& D)$ pada level 3. Penelitian ini bertujuan untuk meneliti dan menguji produk, sehingga berorientasi pada produk(10). Prosedur penelitian diadaptasi dari langkah-langkah Borg dan Gall, bahwa dimungkinkan untuk membatasi penelitian dalam skala kecil, termasuk membatasi langkah penelitian(11). Penerapan langkah penelitian disesuaikan dengan kebutuhan peneliti(12). Terkait keterbatasan waktu dan biaya, langkahlangkah penelitian disederhanakan menjadi 4, yaitu (1) melakukan analisis produk yang akan dikembangkan, (2) mengembangkan produk awal, (3) validasi ahli dan revisi, (4) uji coba lapangan dalam skala kecil(13).

Adanya keterbatasan waktu dan biaya, pada penelitian dan pengembangan dilaksanakan hanya sampai pada uji coba lapangan skala kecil dengan tujuan terciptanya alat peraga permainan edukasi kesehatan yang inovatif, implementatif, dan terpantau pada anak usia antara 7-13 tahun yang layak dan dapat digunakan. Subjek dalam penelitian ini adalah siswa SD Negeri Glagahsari dan SD Muhammadiyah Sokonandi (keduanya di Kota Yogyakarta), usia 7-13 tahun, 
berjumlah 6 siswa sebagai subjek uji coba lapangan dalam skala kecil.

Teknik pengumpulan data dengan menggunakan angket/instrumen. dengan responden, ahli materi, ahli media, dan siswa. Dalam penelitian ini ada dua jenis data yang dianalisis. Pertama, data kualitatif, berupa kritik dan saran dari yang dikemukakan oleh ahli media dan ahli materi pada saat pengumpulan data dan validasi permainan Leghezo, dihimpun dan dirangkum sebagai pedoman untuk memerbaiki permainan yang dikembangkan. Kedua, data kuantitatif, diperoleh dari hasil penilaian ahli materi, ahli media, dan siswa. Data kuantitatif dianalisis menggunakan statistik deskriptif. Teknik analisis data untuk ahli materi dan ahli media menggunakan statistik deskriptif, dikonversikan menjadi data kuantitatif skala 5, dengan acuan konversi dari Widoyoko sebagai berikut(14):

Tabel 1. Klasifikasi penilaian total

\begin{tabular}{|c|c|c|}
\hline Rumus & Rerata Skor & Klasifikasi \\
\hline$X>\bar{X}_{i}+1,8 \times s b_{i}$ & $>4,2$ & Sangat baik \\
\hline $\bar{X}_{i}+0,6 \times s b_{i}<X \leq X_{i}+1,8 \times s b_{i}$ & $3,4-4,2$ & Baik \\
\hline $\bar{X}_{i}-0,6 \times s b_{i}<X \leq X_{i}+0,6 \times s b_{i}$ & $2,6-3,4$ & Cukup \\
\hline $\bar{X}_{i}-1,8 \times s b_{i}<X \leq X_{i}-0,6 \times s b_{i}$ & $1,8-2,6$ & Kurang \\
\hline$X \leq \bar{X}_{i}-1,8 \times s b_{i}$ & $\leq 1,8$ & Sangat kurang \\
\hline
\end{tabular}

Keterangan:

$\bar{X}_{\bar{i}} \quad=$ Rerata ideal $=1 / 2($ skor maksimal + skor minimal $)$

$s b_{i} \quad=$ Simpang baku ideal $=16 /($ skor maksimal - skor minimal $)$

$\mathrm{X}=$ Skor aktual

Permainan edukasi Leghezo dikatakan layak sebagai alat peraga permainan kesehatan yang inovatif, edukatif, implementatif, dan terpantau bagi anak-anak usia 7-13 tahun, jika hasil penilaian yang didapatkan, minimal dengan kriteria "baik". Teknik analisis data untuk subjek uji coba menggunakan skala Guttman, yang terdapat pada tabel berikut(15) :

Tabel 2. Penilaian total instrumen siswa

\begin{tabular}{|c|c|}
\hline Persentase & Kategori \\
\hline $\bar{x} \geq 75 \%$ & Layak \\
\hline $\bar{x} \leq 75 \%$ & Tidak layak \\
\hline
\end{tabular}

Permainan edukasi kesehatan Leghezo dikatakan "layak" digunakan untuk anakanak usia antara 7-13 tahun, jika persentase kelayakan mencapai $>76 \%$. Sebaliknya, dikatakan "tidak layak" jika persentase kelayakan mencapai $\leq 76 \%$.

\section{HASIL PENELITIAN DAN PEMBAHASAN}

Pada perencanaan dilakukan perancangan dengan mengembangkan bentuk permainan edukasi kesehatan berupa Leghezo (Let's Go to The Health Zone), dengan uji Research and Development $(R \& D)$ menurut teori Borg and Gall, yang dilakukan sampai tahapan ke-4 saja(11). Pengembangan produk awal melalui proses dan langkah sebagai berikut: (1) merumuskan isi materi permainan Leghezo, (2) mengumpulkan alat dan bahan-bahan yang diperlukan dalam mengembangkan permainan Leghezo, (3) melakukan pengembangan produk dengan mendesain komponen-komponen permainan Leghezo, terdiri dari 10 jenis komponen permainan, sebagai berikut: 
Tabel 3. Jenis komponen permainan Leghezo

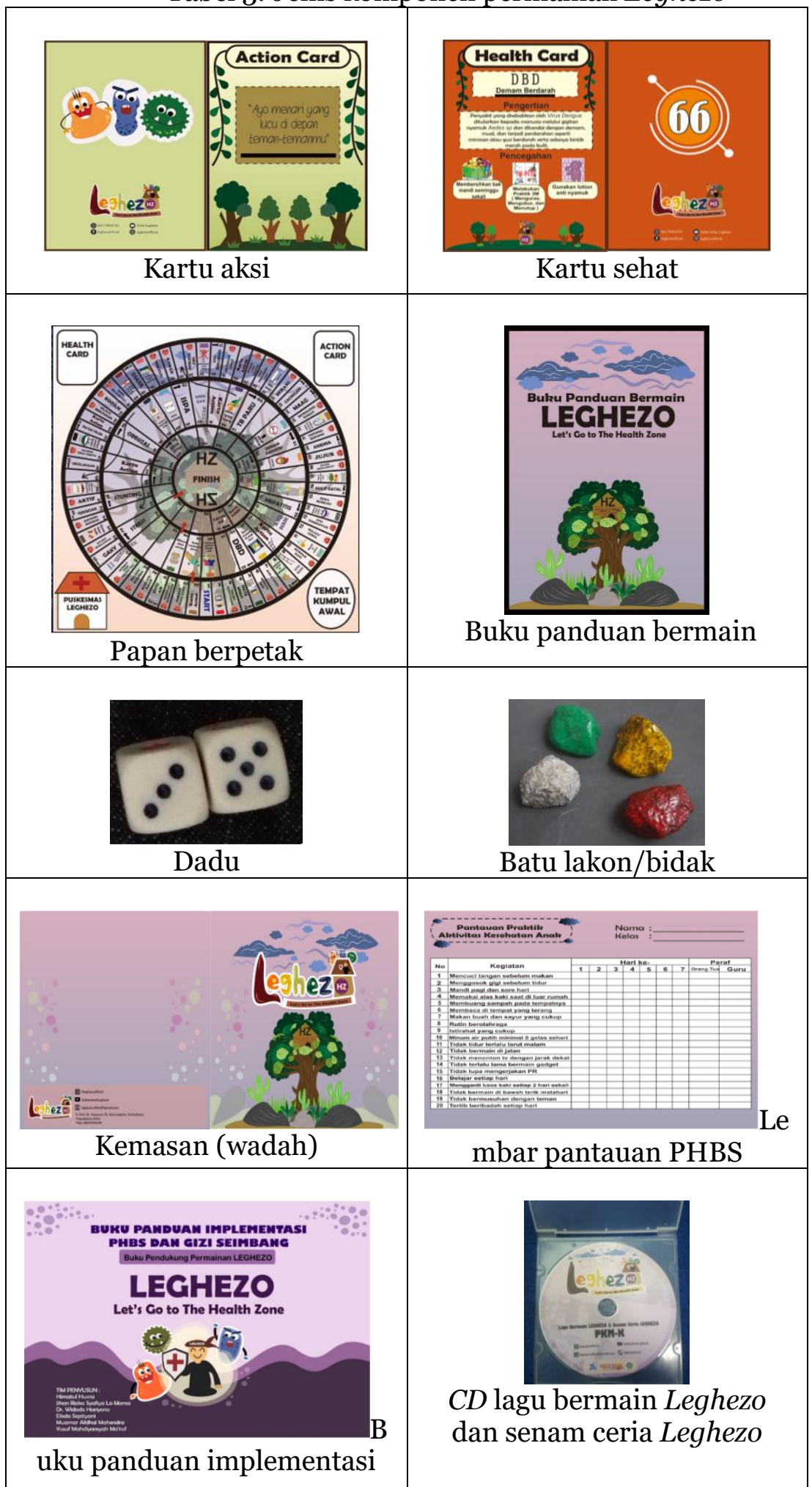

Evaluasi media dilakukan dengan meminta pertimbangan (validasi) ahli, terdiri dari ahli materi dan ahli media. Validasi "materi" dilakukan oleh ahli pada Seksi Promosi Kesehatan, Dinas Kesehatan Kota Yogyakarta. Ahli materi melakukan validasi materi melalui satu tahapan saja, dengan memberi skor 44, dengan rata-rata 4,9, termasuk kategori sangat baik. Ahli materi menyatakan, bahwa permainan edukasi kesehatan Leghezo layak dan sangat baik untuk diuji tanpa revisi. Adapun validasi "media" dilakukan oleh Dosen pada Fakultas Kesehatan Masyarakat (FKM) Universitas Ahmad Dahlan (UAD) Yogyakarta, dengan melalui tiga tahapan validasi. Tahap I diperoleh jumlah skor 139, dengan rata-rata 4,21, termasuk kategori sangat baik. Diberikan saran untuk menambahkan tokoh atau ikon Leghezo untuk menjadi ciri khas permainan tersebut. Tahap II diperoleh jumlah skor 143, dengan rata-rata 4,33, sehingga dikategorikan sangat 
baik. Namun, masih ada saran untuk memerbaiki atau merevisi pada desain buku pendamping, terutama ekspresi gambar dua kuman (warna hijau dan oranye) yang menunjukkan eskpresi friendly atau ramah, sedangkan kuman yang warna biru memiliki ekspresi yang sudah sesuai. Tahap III diperoleh jumlah skor 144, dengan rata-rata 4,36 , berarti sangat baik. Ahli media menyatakan bahwa permainan Leghezo layak dan sangat baik untuk diuji cobakan tanpa direvisi.

Uji coba lapangan awal, dilakukan pada tujuh siswa SD usia 7-13 tahun, di SD Negeri Glagahsari dan SD Muhammadiyah Sokonandi. Hasil uji coba lapangan diperoleh jumlah penilaian 9, dengan maksimal penilaian 9. Jika jumlah skor tersebut dipersentasekan, bahwa permainan edukasi kesehatan Leghezo berkategori layak. Berdasarkan pengamatan selama bermain Leghezo, anak-anak memahami dan mengerti jalannya permainan Leghezo, sehingga mereka antusias dan gembira dalam bermain. Setelah itu, anak-anak diberikan kuesioner dengan mengisi pertanyaan mengenai permainan Leghezo. Anak-anak mengisinya dengan memahami pertanyaan dan mampu menjawab dengan mudah. Diperoleh hasil, permainan Leghezo mendapatkan respon yang baik dari siswa SD berdasarkan hasil uji lapangan secara awal.

Konsep dibuatnya Leghezo adalah dikembangkannya sebuah permainan edukasi kesehatan yang dapat digunakan oleh anak-anak untuk mencegah terkena sakit dan mampu menerapkan PHBS dalam keseharian. Adanya permainan edukasi kesehatan yang diinovasikan, diharapkan mampu mengoptimalkan kesehatan fisik, mental, spiritual, dan sosial bagi anak-anak usia SD. Leghezo adalah permainan berpetak berbentuk melingkar yang didukung desain bergambar full color, dengan mengedepankan 4 unsur, yaitu: (1) inovatif, (2) edukatif, (3) implementatif, (4) terpantau. Penawaran permainan baru dengan desain berpetak terdiri dari lingkaran luar, tengah, dan dalam, sehingga menambah keingintahuan anak-anak untuk bisa menyelesaikan permainan sampai ke lingkaran bagian dalam. Permainan ini dilengkapi dengan dadu dan batu lakon/bidak. Selain itu, terdapat juga 2 jenis kartu, yaitu (1) health card, yang berisi penjelasan dan cara pencegahan penyakit, (2) action card, yang berisi perintah-perintah lucu untuk menghilangkan ketegangan mental ketika memainkan Leghezo.

Keuntungan permainan Leghezo, dilengkapi dengan buku panduan yang dapat menjelaskan alur dan peraturan permainan. Diperlukan kerjasama dengan guru dan orang tua, agar anak-anak dapat menerapkan permainan dalam kehidupan sehari-hari. Hal yang menarik, pemain dan pemenang diberi hadiah khusus oleh guru, kemudian guru meminta anak untuk menerapkan cara hidup bersih dan sehat (edukasi kesehatan) secara baik dan benar (implementatif), sesuai buku panduan. Jika anak menerapkan hidup bersih dan sehat, maka formulir pantauan ditanda-tangani oleh orang tua dan guru (sangat terpantau).

Permainan edukasi kesehatan Leghezo telah memenuhi syarat dalam pengembangan permainan edukasi kesehatan yang layak. Kelayakan permainan ini dilakukan melalui beberapa tahap uji coba untuk mendapatkan saran, sehingga permainan Leghezo yang telah dikembangkan, layak digunakan sebagai permainan edukasi kesehatan pada anak-anak. Tahapan dalam penelitian ini meliputi tahap validasi yang terdiri dari validasi ahli materi, validasi ahli media, dan uji coba lapangan secara awal.

Pada validasi ahli materi dilakukan dalam satu tahapan dengan memeroleh penilaian sangat baik. Terdapat saran melalui wawancara ahli materi, yaitu media ini sangat baik karena mengajarkan anak untuk dapat menerapkan PHBS dan mengoptimalkan waktu anak untuk bermain sambal belajar. Adapun komponen lainnya, yaitu buku pendamping PHBS sangat membantu anak-anak, guru, dan orang tua pada aspek pengetahuan kesehatan fisik, mental, spiritual, dan sosial, yang ditampilkan melalui petak-petak pada papan permainan Leghezo.

Validasi media dilakukan melalui tiga tahap untuk mendapatkan hasil terbaik pada produk media permainan Leghezo yang dikembangkan. Pada tahap I, diperoleh penilaian dengan kategori sangat baik dan ada beberapa bagian yang harus diperbaiki, yaitu tokoh atau ikon Leghezo agar ditampilkan lebih menonjol, dan penyempurnaan isi buku pendamping. Tahap II, penilaian media mengalami peningkatan karena memeroleh penilaian dengan kategori sangat baik. Pada tahap ini ahli media menyatakan bahwa tokoh atau ikon Leghezo, yaitu gambar virus atau 
kuman pada buku pendamping diperbaiki, terutama pada ekspresi yang mencerminkan kuman memiliki watak yang jahat. Pada tahap III, penilaian media juga mengalami peningkatan dengan kategori permainan sangat baik, sehingga ahli media menyatakan bahwa permainan Leghezo sudah tidak ada lagi bagian yang harus diperbaiki. Dapat dinyatakan, permainan tersebut layak untuk digunakan tanpa revisi dan dapat diuji cobakan kepada para pengguna.

Pada tahap uji coba, peneliti hanya melakukan uji coba lapangan awal. Pada uji lapangan awal, melibatkan 7 siswa SD, dan mendapatkan persentase 100\%, yaitu termasuk kategori layak. Respon dari subjek uji coba, antara lain mereka sangat antusias dan menyukai permainan Leghezo tersebut. Mereka bisa saling berinteraksi dengan teman-teman saat harus melakukan tantangan pada kartu aksi (action card) dan saling memberikan informasi berupa pengetahuan kesehatan melalui kartu sehat (health card).

Selain itu, anak-anak juga diberikan penghargaan atau hadiah (reward) bagi pemain yang bisa menerapkan salah satu PHBS yang sudah didapatkan saat bermain tersebut, kemudian dipantau melalui lembar pemantauan selama satu pekan, dan aktivitas tersebut diamati oleh orang tua si anak. Jika anak melakukan aktivitas sesuai yang diinstruksikan, maka orang tua memberikan tanda tangan pada kertas lembar pemantauan, Akhirnya, kertas tersebut dibawa anak ke sekolah dan dikumpulkan kepada guru. Jika terpenuhi selama satu pekan dalam melakukan salah satu penerapan PHBS, misalnya selalu mencuci tangan sebelum makan, maka anak diberikan penghargaan atau hadiah oleh gurunya.

Berdasarkan penilaian yang telah didapatkan melalui proses validasi ahli media, ahli materi, dan siswa SD Negeri Glagahsari dan SD Muhammadiyah Sokonandi sebagai pengguna produk sekaligus subjek uji coba lapangan awal, dapat dinyatakan bahwa permainan edukasi kesehatan Leghezo yang dikembangkan dan diinovasikan, dinyatakan layak untuk digunakan dalam proses tumbuh kembang anak pasca golden ages, untuk memahami dan menerapkan PHBS dalam keseharian yang dijadikan kebiasaan sejak dini.

\section{KESIMPULAN DAN SARAN}

Dapat disimpulkan, bahwa penilaian permainan Leghezo pada tahap akhir dari ahli media didapatkan skor 4,36 dengan kategori sangat baik atau layak. Penilaian ahli materi didapatkan skor 4,9 dengan kategori sangat baik atau layak. Pada uji coba lapangan awal mendapatkan persentase $100 \%$ dengan kategori layak. Adapun sarannya: (1) bagi para guru, diharapkan untuk memanfaatkan peluang adanya permainan Leghezo pada para siswanya, agar dapat menerapkan kebiasaan yang baik sejak dini melalui PHBS, (2) bagi para orang tua, diharapkan untuk memfasilitasi permainan pada para putranya dalam kesehariannya, dan memantau optimalitasnya, (3) bagi para siswa SD, diharapkan permainan Leghezo dapat diterapkan secara konsisten pada konten pesan-pesan kesehatannya dalam kegiatan keseharian mereka.

\section{Ucapan Terima Kasih}

Ucapan terima kasih disampaikan kepada Himatul Husna, Jihan Rizka Syafiya La Moma, Muamar Afdhal Mahendra, dan Yusuf Mahdiansyah Ma'ruf, yang secara bersama telah berperan besar dalam pembuatan produk Leghezo.

\section{REFERENSI:}

1. Chan F, Pamela IS, Larashinta S, Yoana A, Mardayani D, Sari RK. Penerapan Nilai Karakter Peduli Sosial Pada Peserta Didik Kelas II di Sekolah Dasar. [Internet]. 2019;6(2): 202-6. Available from: http://ojs.unpkediri.ac.id/index.php/efektor-eDOI: https://doi.org/ 10.29407/ e.v6i2.13749.

2. Rahman U. Karakteristik Perkembangan Anak Usia Dini. Jurnal Lentera Pendidikan. 2009;12(1): 46-57.

3. Delima R, Arianti N., Pramudyawardani B. Pengembangan Aplikasi Permainan Edukasi untuk Anak Prasekolah Menggunakan Pendekatan Child Centered Design. Jurnal Informasi. 2016;12(1): 12-23.

4. Susanto A. Perkembangan Anak Usia Dini. Jakarta: Kencana Prenada Media 
Group; 2011.

5. Prasetia SA, Komaini A. Pengaruh Permainan Tradisional Terhadap Peningkatan Kemampuan Motorik Kasar Pada Siswa Putra Sekolah Dasar Negeri 166/III Cut Mutia Kerinci. Jurnal Stamina. 2019;2(6): 65-77.

6. Jamali YR. Model dan Sistem Komunikasi Pembelajaran. Jurnal Ilmu Sustainabilitas [Internet]. 2019; 2(2): 154-75. Available from: http://www.medukasi.web.id/.

7. Aziz F, Nurjanah F, Sari DP. Aktualisasi TTB (Teori Taksonomi Bloom) Melalui Drama Kepahlawanan Guna Penanaman Pendidikan Karakter Pada Peserta Didik. FKIP E-Proceeding PBSI Universitas Jember. Jember. 2017. Hal: 715724 .

8. Viandari KD, Susilawati KPA. Peran Pola Asuh Orangtua dan Penggunaan Gadget Terhadap Interaksi Sosial Anak Prasekolah. Jurnal Psikologi Udayana. 2019; 6(1): 76-87.

9. Solekhah S. Pengembangan Media Monopoli Tematik Pada Tema "Tempat Tinggalku \& Quot; untuk Siswa Kelas IV di SDN Babarsari. E-Jurnal Skripsi Program Studi Teknologi Pendidikan [Internet]. 2015, Juli 30 [cited 2019 Aug 19]; 4 (1). Available from: http://journal.student.uny.ac.id/ ojs/ojs/index.php /fiptp/article/view/887.

10. Sugiyono. Metode Penelitian Kuantitatif, Kualitatif, dan $R \&$ D. Bandung: Alfabeta; 2012.

11. Borg W, Gall M. Educational Research, An Intruction. Fourth Edition. New York: Longman; 1983.

12. Emzir. Metode Penelitian Pendidikan: Kuantitatif dan Kualitatif. Jakarta: Raja Grafindo Persada; 2013.

13. Sugiyono. Metode Penelitian Pendidikan, Pendekatan Kuantitatif, Kualitatif, dan R \& D. Bandung: Alfabeta; 2014.

14. Widoyoko EP. Evaluasi Program Pembelajaran. Yogyakarta: Pustaka Pelajar; 2009.

15. Sugiyono. Metode Penelitian. Bandung: Alfabeta; 2004. 